\title{
Quality of life among patients from urban and rural areas with advanced age-related macular degeneration assessed using the NEI-VFQ-25
}

\author{
Anna Święch ${ }^{1, A-F \oplus}$, Joanna Dolar-Szczasny, ${ }^{1, A, C-D, F \oplus}{ }^{\oplus}$, Dominika Wróbel-Dudzińska ${ }^{2, A-C, F}{ }^{\oplus}$, \\ Ewa Kosior-Jarecka ${ }^{2, A-B, E-F \oplus}$, Jerzy Mackiewicz ${ }^{1, A, E-F} \oplus$ \\ ${ }^{1}$ Department of Vitreoretinal Surgery, Medical University, Lublin, Poland \\ 2 Department Diagnostics and Microsurgery of Glaucoma, Medical University, Lublin, Poland \\ A - Research concept and design, B - Collection and/or assembly of data, C - Data analysis and interpretation, \\ $D$ - Writing the article, $E$ - Critical revision of the article, $F$ - Final approval of article
}

\begin{abstract}
Święch A, Dolar-Szczasny J, Wróbel-Dudzińska D, Kosior-Jarecka E, Mackiewicz J. Quality of life among patients from urban and rural areas with advanced age-related macular degeneration assessed using the NEI-VFQ-25. Ann Agric Environ Med. 2021 ; $28(2)$ : $243-249$. doi: $10.26444 /$ aaem/130436
\end{abstract}

\section{Abstract}

Objective. The aim of the study was to explore the influence of exudative age-related macular degeneration on the quality of life of patients from urban and rural areas.

Materials and method. The retrospective study included 144 Polish Caucasians with exudative age-related macular degeneration, treated with anti-VEGF, recruited from Department of Medical Retina in Lublin between March and June 2017. Clinical assessment included age, gender, visual acuity, complete ophthalmic examination, fundus fluorescein angiography and optical coherence tomography, medical history and the NEI VFQ-25 questionnaire.

Results. The mean age of the study group was $76.73 \pm 12.3$ years, average time of AMD was $4.24 \pm 4.1$ years. $21.5 \%$ of patients reported comorbidities such as hypertension, cardiovascular disease, diabetes mellitus. 99 (68.75\%) lived in a city, while $45(31.25 \%)$ in a village. There was a tendency of females to complain more than males about moderate and severe discomfort and pain $(\mathrm{p}=0.09$ ). Most of the patients did not drive a car before the onset of the disease (female vs.male: $81 \%$ vs $62.9 \%$; $p=0.01) .62 .8 \%$ males and $25.8 \%$ females gave up driving $(p=0.003)$, whereas significantly more males gave up driving' and $25 \%$ of villagers gave up driving $(p=0.07)$. The parameter because of the eyesight - female vs. male: $50 \%$ vs. $20.8 \% ; p=0.03$. There was a tendency of village respondents to complain more often about extreme difficulty in reading newspapers, street signs or the names of stores than $(p=0.08) .44 .2 \%$ city residents. Rural patients felt to achieve much less because of their eyesight, which was not observed in patients from the city $(p=0.06)$.

Conclusions. The place of residence and gender influenced perception of the disease in exudative form of age-related macular degeneration.

\section{Key words \\ AMD, rural areas, urban areas, quality of life}

\section{INTRODUCTION}

Age-related macular degeneration (AMD) is the leading cause of irreversible visual impairment and legal blindness in developed countries, affecting mainly people older than 60 years. Approximately 30 million people nowadays suffer from AMD, accounting for $8.7 \%$ of the whole population worldwide. It is estimated that the number of AMD affected patients will increase to 288 million by 2040 [1].

AMD is a progressive disease that severely impaires central vision. There are two clinical forms of AMD: dry AMD, characterised by retinal pigment epithelium alterations, drusen, atrophy and exudative AMD. In particular, the exudative form of AMD, complicated by choroidal neovascularization, presents a severe vision-affecting condition in which the subretinal neovascular membrane progresively destroys the retinal layers. Intravitreal antiVEGF (vascular endothelial growth factor) agents are used for treatment of this type of disease. AMD excerts an impact on many aspects of everyday functioning and independent

Address for correspondence: Anna Święch, Department of Vitreoretinal Surgery Medical University, Lublin, Poland

E-mail: anna.zub@umlub.pl

Received: 29.05.2020; accepted: 13.11.2020; first published: 01.12.2020 life, such as ability to read, shopping, driving and cooking for oneself [2]. Patients with advanced stages of AMD may also suffer emotional distress and depression, anxiety and social isolation which finally result in reduced health-related quality of life (HRQoL) [3, 4, 5].

In 2001, the National Eye Institute Visual Functioning Questionnaire (NEI-VFQ-25) scale was developed to determine QoL among patients with chronic blindness, including AMD. The scale provides an evaluation of the impact of visual impairment on the emotional wellbeing, social relationships and daily activities of patients with chronic blindness [6].

Although the effects of exudative AMD on the quality of life have been studied extensively in well-developed countries, no data exists comparing the quality of life of patients with AMD from urban and rural regions. Different social habbits, everyday activities and cultural characteristics in different communities may lead patients to be influenced psychologically in different manners from the same disease.

A good understanding by others can potentially improve AMD patients' quality of life by, for example, increasing empathy for persons affected by AMD, allowing cohabitants to provide practical help in everyday activities and social life. 


\section{OBJECTIVE}

The aim of the study is to explore the influence of life experience and perception of AMD patients from urban and rural areas of the Lublin Region of estern Poland. The QoL was assesed by NEI-VFQ-25. Obtained results can help to understand the possible different needs and habits of AMDaffected patients from two different enviroments.

\section{MATERIALS AND METHOD}

The retrospective study included 144 Polish Caucasians with exudative age-related macular degeneration, treated with anti-VEGF, recruited in the Department of Medical Retina at the Ophthalmic Clinic in Lublin between March - June 2017. Exudative AMD was diagnosed and defined as occurrences of intra- or subretinal fluid due to choroidal neovascularization with or without drusen, and retinal pigment epithelial detachment.

Exclusion criteria: glaucoma, any optic neuropathy, diabetic retinopathy and maculopathy, severe media opacity, including advanced cataract, uveitis, amblyopia, degenerative myopia, retinitis pigmentosa, and vision problems secondary to cerebrovascular accidents.

Informed consent was obtained from all the patients before inclusion according to the recommendations of the Declaration of Helsinki, and after approval by the Ethical Committee of Lublin University.

Clinical assessment included age, gender, visual acuity, fundus fluorescein angiography and optical coherence tomography (Spectralis OCT by Heidelberg Engineering, Germany), history of medical conditions, presence of comorbidities (hypertension, cardiovascular disease, diabetes mellitus, thyroid problems) and the NEI VFQ-25 questionnaire. Patients underwent a complete ophthalmic examination.

The patient's place of residence was checked. The differentiation between village and city was made according to the list of Polish localities published in 2012 by Polish Ministry of Administration and Digitization.

The visual acuity was measured for far (at $5 \mathrm{~m}$ ) and reported as Logmar values, and near distance (at $30-40 \mathrm{~cm}$ ) according to Snellen charts. The NEI VFQ-25 questionnaire consists of 25 questions which measure the subjective assessment of patient-reported answers about general health, general vision, vision-specific mental health, vision-specific social functioning, vision-specific dependency, ocular pain, near and distant activities, role limitations, colour vision and peripheral vision. The overall composite score is calculated by taking the mean of all the NEI VFQ-25 subscales, excluding the general health subscale. [http://www.nei.nih. gov/resouces/visionfunction/manual_cm2000.pdf.]

Statistic evaluation of the data was performed using Statistica 13.1. The continuous data were presented mainly as mean $\pm \mathrm{SD}$, whereas categorical data as the number of patients or percentage values. A p-value of less than 0.05 was considered statistically significant. A p-value higher than 0.05 and lower than 0.1 was considered as a statistical tendency. Normal distribution was checked with the Shapiro-Wilk test. The Mann-Whitney test was used for non-normally distributed data. Quantitative variables with normal distribution were analysed with the paired Student t-test. Proportions were analysed by means of the chi-square test with Yates correction when needed.

\section{RESULTS}

The mean age of the study group was $76.3 \pm 12.3$ years: males - 74.06 \pm 9.07 , females - 76.49 \pm 8.02 years; average time of AMD - 4.24 \pm 4.1 years. Visual acuity among patients was $0.28 \pm 0.28$ and near $0.76 \pm 0.79 .21 .5 \%$ of patients reported comorbidities such as hypertension, cardiovascular disease, diabetes mellitus.

$99(68.75 \%)$ of the patients lived in a city, while $45(31.25 \%)$ lived in a village. (Tab. 1).

Table 1. Demographics and clinical characteristics of the studied group.

\begin{tabular}{lcc}
\hline Feature & Male & Female \\
\hline Number & $56(38.8 \%)$ & $88(61.2 \%)$ \\
\hline Age(years) & $74.06 \pm 9.07$ & $76.49 \pm 8.02$ \\
\hline BCVA far & $0.55 \pm 0.55$ & $0.52 \pm 0.55$ \\
\hline BCVA near & $0.82 \pm 0.81$ & $0.71 \pm 0.77$ \\
\hline Time of AMD (years) & $4.36 \pm 3.89$ & $4.15 \pm 4.37$ \\
\hline History of cardiovascular problem & $12(21.4 \%)$ & $19(21.6 \%)$ \\
\hline
\end{tabular}

Detailed analysis of the NEI-VGQ-25 questionnaire in the study group are shown in Table 2

Detailed analysis of the NEI-VGQ-25 questionnaire between women and men is showed in Table 2 .

Table 2. NEI VFQ-25 results

\begin{tabular}{|c|c|c|c|c|c|}
\hline & NEI VFQ-25 questionnaire & Possible answers & $\begin{array}{l}\text { Number of } \\
\text { patients (\%) }\end{array}$ & $\begin{array}{c}\mathrm{p} \\
\text { Female vs. } \\
\text { Male }\end{array}$ & $\begin{array}{c}\text { P } \\
\text { City vs. } \\
\text { Village }\end{array}$ \\
\hline \multirow{5}{*}{1} & \multirow{5}{*}{$\begin{array}{l}\text { In general. would you say your overall } \\
\text { health is: }\end{array}$} & 1. Excellent & $2(1.4)$ & \multirow{5}{*}{0.9} & \multirow{5}{*}{$<0.00001^{*}$} \\
\hline & & 2. Very Good & $4(2.8)$ & & \\
\hline & & 3. Good & $50(34.9)$ & & \\
\hline & & 4. Fair & $54(37.8)$ & & \\
\hline & & 5. Poor & $33(23.1)$ & & \\
\hline \multirow{6}{*}{2} & \multirow{6}{*}{$\begin{array}{l}\text { At the present time, would you say your } \\
\text { eyesight using both eyes (with glasses } \\
\text { or contact lenses, if you wear them) is } \\
\text { excellent, good, fair, poor, or very p, or are } \\
\text { you completely blind? }\end{array}$} & 1. Excellent & 0 & \multirow{6}{*}{0.67} & \multirow{6}{*}{$<0.00001 *$} \\
\hline & & 2. Good & $21(14.7)$ & & \\
\hline & & 3. Fair & $51(35.7)$ & & \\
\hline & & 4. Poor & $62(43.3)$ & & \\
\hline & & 5. Very poor & $8(5.6)$ & & \\
\hline & & 6. Completely blind & $1(0.7)$ & & \\
\hline
\end{tabular}




\begin{tabular}{|c|c|c|c|c|c|}
\hline & NEI VFQ-25 questionnaire & Possible answers & $\begin{array}{l}\text { Number of } \\
\text { patients (\%) }\end{array}$ & $\begin{array}{l}\mathrm{p} \\
\text { Female vs. } \\
\text { Male }\end{array}$ & $\begin{array}{l}\text { P } \\
\text { City vs. } \\
\text { Village }\end{array}$ \\
\hline 3 & $\begin{array}{l}\text { How much of the time do you worry about } \\
\text { your eyesight? }\end{array}$ & $\begin{array}{l}\text { 1. None of the time } \\
\text { 2. A little of the time } \\
\text { 3. Some of the time } \\
\text { 4. Most of the time } \\
\text { 5. All of the time }\end{array}$ & $\begin{array}{c}4(2.8) \\
8(5.6) \\
33(23.1) \\
42(29.4) \\
56(39.1)\end{array}$ & 0.41 & 0.3108 \\
\hline 4 & $\begin{array}{l}\text { How much pain or discomfort have you } \\
\text { had in and around your eyes (for example, } \\
\text { burning, itching, or aching)? } \\
\text { Would you say it is: }\end{array}$ & $\begin{array}{l}\text { 1. None } \\
\text { 2. Mild } \\
\text { 3. Moderate } \\
\text { 4. Severe } \\
\text { 5. Very severe }\end{array}$ & $\begin{array}{c}39(27.3) \\
39(27.3) \\
56(39.1) \\
8(5.6) \\
1(0.7)\end{array}$ & $0.0907 \wedge$ & 0.934 \\
\hline 5 & $\begin{array}{l}\text { How much difficulty do you have reading } \\
\text { ordinary print in newspapers? } \\
\text { Would you say you have: }\end{array}$ & $\begin{array}{l}\text { 1. No difficulty at all } \\
\text { 2. A little difficulty } \\
\text { 3. Moderate difficulty } \\
\text { 4. Extreme difficulty } \\
\text { 5. Stopped doing this because of your eyesight } \\
\text { 6. Stopped doing this for other reasons, or not interested in doing this }\end{array}$ & $\begin{array}{l}12(8.4) \\
18(12.6) \\
47(32.9) \\
25(17.5) \\
38(26.6) \\
3(2.1)\end{array}$ & 0.744 & $0.0883 \wedge$ \\
\hline 6 & $\begin{array}{l}\text { How much difficulty do you have doing } \\
\text { work or hobbies that require you to see well } \\
\text { up close, such as cooking, sewing, fixing } \\
\text { things around the house, or using hand } \\
\text { tools? Would you say: }\end{array}$ & $\begin{array}{l}\text { 1. No difficulty at all } \\
\text { 2. A little difficulty } \\
\text { 3. Moderate difficulty } \\
\text { 4. Extreme difficulty } \\
\text { 5. Stopped doing this because of your eyesight } \\
\text { 6. Stopped doing this for other reasons, or not interested in doing this }\end{array}$ & $\begin{array}{l}14(9.8) \\
20(13.9) \\
54(37.8) \\
36(25.2) \\
16(11.2) \\
3(2.1)\end{array}$ & 0.319 & 0.406 \\
\hline 7 & $\begin{array}{l}\text { Because of your eyesight, how much } \\
\text { difficulty do you have finding something on } \\
\text { a cluttered shelf? }\end{array}$ & $\begin{array}{l}\text { 1. No difficulty at all } \\
\text { 2. A little difficulty } \\
\text { 3. Moderate difficulty } \\
\text { 4. Extreme difficulty } \\
\text { 5. Stopped doing this because of your eyesight } \\
\text { 6. Stopped doing this for other reasons, or not interested in doing this }\end{array}$ & $\begin{array}{l}35(24.5) \\
27(18.9) \\
55(38.5) \\
24(16.8) \\
1(0.7) \\
1(0.7)\end{array}$ & 0.975 & 0.168 \\
\hline 8 & $\begin{array}{l}\text { How much difficulty do you have reading } \\
\text { street signs or the names of stores? }\end{array}$ & $\begin{array}{l}\text { 1. No difficulty at all } \\
\text { 2. A little difficulty } \\
\text { 3. Moderate difficulty } \\
\text { 4. Extreme difficulty } \\
\text { 5. Stopped doing this because of your eyesight } \\
\text { 6. Stopped doing this for other reasons, or not interested in doing this }\end{array}$ & $\begin{array}{c}38(26.6) \\
35(24.5) \\
38(26.6) \\
28(19.6) \\
3(2.1) \\
1(0.7)\end{array}$ & 0.751 & $0.0823 \wedge$ \\
\hline 9 & $\begin{array}{l}\text { Because of your eyesight, how much } \\
\text { difficulty do you have going down steps, } \\
\text { stairs, or curbs in dim light or at night? }\end{array}$ & $\begin{array}{l}\text { 1. No difficulty at all } \\
\text { 2. A little difficulty } \\
\text { 3. Moderate difficulty } \\
\text { 4. Extreme difficulty } \\
\text { 5. Stopped doing this because of your eyesight } \\
\text { 6. Stopped doing this for other reasons, or not interested in doing this }\end{array}$ & $\begin{array}{c}20(13.9) \\
36(25.2) \\
42(29.4) \\
36(25.2) \\
5(3.5) \\
4(2.8)\end{array}$ & 0.1977 & 0.3493 \\
\hline 10 & $\begin{array}{l}\text { Because of your eyesight, how much } \\
\text { difficulty do you have noticing objects off to } \\
\text { the side while walking along? }\end{array}$ & $\begin{array}{l}\text { 1. No difficulty at all } \\
\text { 2. A little difficulty } \\
\text { 3. Moderate difficulty } \\
\text { 4. Extreme difficulty } \\
\text { 5. Stopped doing this because of your eyesight } \\
\text { 6. Stopped doing this for other reasons, or not interested in doing this } \\
\text { interested in doing this }\end{array}$ & $\begin{array}{c}39(27.3) \\
36(25.2) \\
44(30.8) \\
20(13.9) \\
2(1.4) \\
2(1.4)\end{array}$ & 0.5884 & 0.2286 \\
\hline 11 & $\begin{array}{l}\text { Because of your eyesight, how much } \\
\text { difficulty do you have seeing how people } \\
\text { react to things you say? }\end{array}$ & $\begin{array}{l}\text { 1. No difficulty at all } \\
\text { 2. A little difficulty } \\
\text { 3. Moderate difficulty } \\
\text { 4. Extreme difficulty } \\
\text { 5. Stopped doing this because of your eyesight } \\
\text { 6. Stopped doing this for other reasons, or not interested in doing this }\end{array}$ & $\begin{array}{c}56(39.2) \\
31(21.7) \\
35(24.5) \\
17(11.9) \\
1(0.7) \\
3(2.1)\end{array}$ & 0.2687 & 0.2310 \\
\hline 12 & $\begin{array}{l}\text { Because of your eyesight, how much } \\
\text { difficulty do you have selecting and } \\
\text { matching your own clothes? }\end{array}$ & $\begin{array}{l}\text { 1. No difficulty at all } \\
\text { 2. A little difficulty } \\
\text { 3. Moderate difficulty } \\
\text { 4. Extreme difficulty } \\
\text { 5. Stopped doing this because of your eyesight } \\
\text { 6. Stopped doing this for other reasons, or not interested in doing this }\end{array}$ & $\begin{array}{c}76(53.1) \\
30(20.9) \\
30(20.9) \\
6(4.2) \\
1(0.7)\end{array}$ & 0.6251 & 0.231 \\
\hline 13 & $\begin{array}{l}\text { Because of your eyesight, how much } \\
\text { difficulty do you have visiting people in their } \\
\text { homes, at parties, or in restaurants? }\end{array}$ & $\begin{array}{l}\text { 1. No difficulty at all } \\
\text { 2. A little difficulty } \\
\text { 3. Moderate difficulty } \\
\text { 4. Extreme difficulty } \\
\text { 5. Stopped doing this because of your eyesight } \\
\text { 6. Stopped doing this for other reasons, or not interested in doing this }\end{array}$ & $\begin{array}{l}60(41.9) \\
32(22.4) \\
33(23.1) \\
13(9.1) \\
2(1.4) \\
3(2.1)\end{array}$ & 0.31 & 0.1383 \\
\hline
\end{tabular}




\begin{tabular}{|c|c|c|c|c|c|}
\hline & NEI VFQ-25 questionnaire & Possible answers & $\begin{array}{l}\text { Number of } \\
\text { patients (\%) }\end{array}$ & $\begin{array}{l}\mathrm{p} \\
\text { Female vs. } \\
\text { Male }\end{array}$ & $\begin{array}{l}\text { P } \\
\text { City vs. } \\
\text { Village }\end{array}$ \\
\hline 14 & $\begin{array}{l}\text { Because of your eyesight, how much } \\
\text { difficulty do you have going out to see } \\
\text { movies, plays, or sports events? }\end{array}$ & $\begin{array}{l}\text { 1. No difficulty at all } \\
\text { 2. A little difficulty } \\
\text { 3. Moderate difficulty } \\
\text { 4. Extreme difficulty } \\
\text { 5. Stopped doing this because of your eyesight } \\
\text { 6. Stopped doing this for other reasons, or not interested in doing this }\end{array}$ & $\begin{array}{l}36(25.2) \\
25(17.5) \\
27(18.9) \\
16(11.2) \\
19(13.3) \\
20(14.0)\end{array}$ & 0.184 & 0.6625 \\
\hline 15 & $\begin{array}{l}\text { Are you currently driving, at least once in } \\
\text { a while? }\end{array}$ & $\begin{array}{l}\text { 1. Yes } \\
\text { 2. No }\end{array}$ & $\begin{array}{r}40(28.6) \\
100(71.4)\end{array}$ & $0.0112^{*}$ & $0.0478 *$ \\
\hline $15 a$ & $\begin{array}{l}\text { IF NO: Have you never driven a car or have } \\
\text { you given up driving? }\end{array}$ & $\begin{array}{l}\text { 1. Never driven } \\
\text { 2. Gave up }\end{array}$ & $\begin{array}{l}56(59.6) \\
38(40.4)\end{array}$ & $0.003^{*}$ & $0.0687 \wedge$ \\
\hline $15 b$ & $\begin{array}{l}\text { IF YOU GAVE UP DRIVING: Was that mainly } \\
\text { because of your eyesight, mainly for some } \\
\text { other reason, or because of both your } \\
\text { eyesight and other reasons? }\end{array}$ & $\begin{array}{l}\text { 1. Mainly eyesight } \\
\text { 2. Mainly other reasons } \\
\text { 3. Both eyesight and other reasons }\end{array}$ & $\begin{array}{l}18(36.7) \\
19(38.8) \\
12(24.5)\end{array}$ & $0.03311^{*}$ & 0.8857 \\
\hline $15 c$ & $\begin{array}{l}\text { IF CURRENTLY DRIVING: How much difficulty } \\
\text { do you have during the daytime in familiar } \\
\text { places? Would you say you have: }\end{array}$ & $\begin{array}{l}\text { 1. No difficulty at all } \\
\text { 2. A little difficulty } \\
\text { 3. Moderate difficulty } \\
\text { 4. Extreme difficulty } \\
\text { 5. Stopped doing this because of your eyesight } \\
\text { 6. Stopped doing this for other reasons, or not interested in doing this }\end{array}$ & $\begin{aligned} & 18(50.0) \\
& 5(13.9) \\
& 7(19.4) \\
& 5(13.9) \\
& 1(2.8) \\
& 0\end{aligned}$ & 0.717 & 0.2658 \\
\hline 16 & $\begin{array}{l}\text { How much difficulty do you have driving at } \\
\text { night? Would you say you have: }\end{array}$ & $\begin{array}{l}\text { 1. No difficulty at all } \\
\text { 2. A little difficulty } \\
\text { 3. Moderate difficulty } \\
\text { 4. Extreme difficulty } \\
\text { 5. Stopped doing this because of your eyesight } \\
\text { 6. Stopped doing this for other reasons, or not interested in doing this }\end{array}$ & $\begin{array}{c}7(14.9) \\
9(19.1) \\
7(14.9) \\
4(8.5) \\
13(27.6) \\
7(14.9)\end{array}$ & 0.722 & 0.5857 \\
\hline $16 a$ & $\begin{array}{l}\text { How much difficulty do you have driving in } \\
\text { difficult conditions, such as in bad weather, } \\
\text { during rush hour, on the freeway, or in city } \\
\text { traffic? Would you say you have: }\end{array}$ & $\begin{array}{l}\text { 1. No difficulty at all } \\
\text { 2. A little difficulty } \\
\text { 3. Moderate difficulty } \\
\text { 4. Extreme difficulty } \\
\text { 5. Stopped doing this because of your eyesight } \\
\text { 6. Stopped doing this for other reasons, or not interested in doing this }\end{array}$ & $\begin{aligned} 8 & (17.4) \\
10 & (21.7) \\
11 & (23.9) \\
1 & (2.2) \\
10 & (21.7) \\
6 & (13.0)\end{aligned}$ & 0.965 & 0.1047 \\
\hline 17 & $\begin{array}{l}\text { Do you accomplish less than you would like } \\
\text { because of your vision? }\end{array}$ & $\begin{array}{l}\text { 1. All of the time } \\
\text { 2. Most of the time } \\
\text { 3. Some of the time } \\
\text { 4. Some of the time } \\
\text { 5. None of the time }\end{array}$ & $\begin{array}{l}31(21.7) \\
28(19.6) \\
38(26.6) \\
22(15.4) \\
22(15.4)\end{array}$ & 0.4536 & $0.0632 \wedge$ \\
\hline 18 & $\begin{array}{l}\text { Are you limited in how long you can work or } \\
\text { do other activities because of your vision? }\end{array}$ & $\begin{array}{l}\text { 1. All of the time } \\
\text { 2. Most of the time } \\
\text { 3. Some of the time } \\
\text { 4. Some of the time } \\
\text { 5. None of the time }\end{array}$ & $\begin{array}{l}23(16.1) \\
33(23.1) \\
39(27.3) \\
21(14.7) \\
26(18.2)\end{array}$ & 0.2207 & 0.2541 \\
\hline 19 & $\begin{array}{l}\text { How much does pain or discomfort in or } \\
\text { around your eyes, for example, burning, } \\
\text { itching, or aching, keep you from doing } \\
\text { what you'd like to be doing? Would you say: }\end{array}$ & $\begin{array}{l}\text { 1. All of the time } \\
\text { 2. Most of the time } \\
\text { 3. Some of the time } \\
\text { 4. A little of the time } \\
\text { 5. None of the time }\end{array}$ & $\begin{array}{c}7(4.9) \\
25(17.4) \\
34(23.8) \\
34(23.8) \\
43(30.1)\end{array}$ & 0.2107 & 0.7808 \\
\hline 20 & $\begin{array}{l}\text { I stay home most of the time because of my } \\
\text { eyesight }\end{array}$ & $\begin{array}{l}\text { 1. Definitely True } \\
\text { 2. Mostly True } \\
\text { 3. Not Sure } \\
\text { 4. Mostly False } \\
\text { 5. Definitely False }\end{array}$ & $\begin{array}{l}19(13.4) \\
29(20.4) \\
11(7.7) \\
21(14.8) \\
62(43.7)\end{array}$ & 0.9312 & 0.2052 \\
\hline 21 & $\begin{array}{l}\text { I feel frustrated a lot of the time because of } \\
\text { my eyesight }\end{array}$ & $\begin{array}{l}\text { 1. Definitely True } \\
\text { 2. Mostly True } \\
\text { 3. Not Sure } \\
\text { 4. Mostly False } \\
\text { 5. Definitely False }\end{array}$ & $\begin{array}{l}21(14.8) \\
30(21.1) \\
18(12.7) \\
22(15.5) \\
51(35.9)\end{array}$ & 0.6630 & $0.0066^{*}$ \\
\hline 22 & $\begin{array}{l}\text { I have much less control over what I d, } \\
\text { because of my eyesight }\end{array}$ & $\begin{array}{l}\text { 1. Definitely True } \\
\text { 2. Mostly True } \\
\text { 3. Not Sure } \\
\text { 4. Mostly False } \\
\text { 5. Definitely False }\end{array}$ & $\begin{array}{l}23(16.2) \\
45(31.7) \\
16(11.3) \\
20(14.1) \\
38(26.8)\end{array}$ & 0.5615 & 0.178 \\
\hline 23 & $\begin{array}{l}\text { Because of my eyesight, I have to rely too } \\
\text { much on what other people tell me }\end{array}$ & $\begin{array}{l}\text { 1. Definitely True } \\
\text { 2. Mostly True } \\
\text { 3. Not Sure } \\
\text { 4. Mostly False } \\
\text { 5. Definitely False }\end{array}$ & $\begin{array}{l}18(12.7) \\
31(21.8) \\
10(7.0) \\
27(19.0) \\
56(39.4)\end{array}$ & 0.4180 & 0.4731 \\
\hline
\end{tabular}




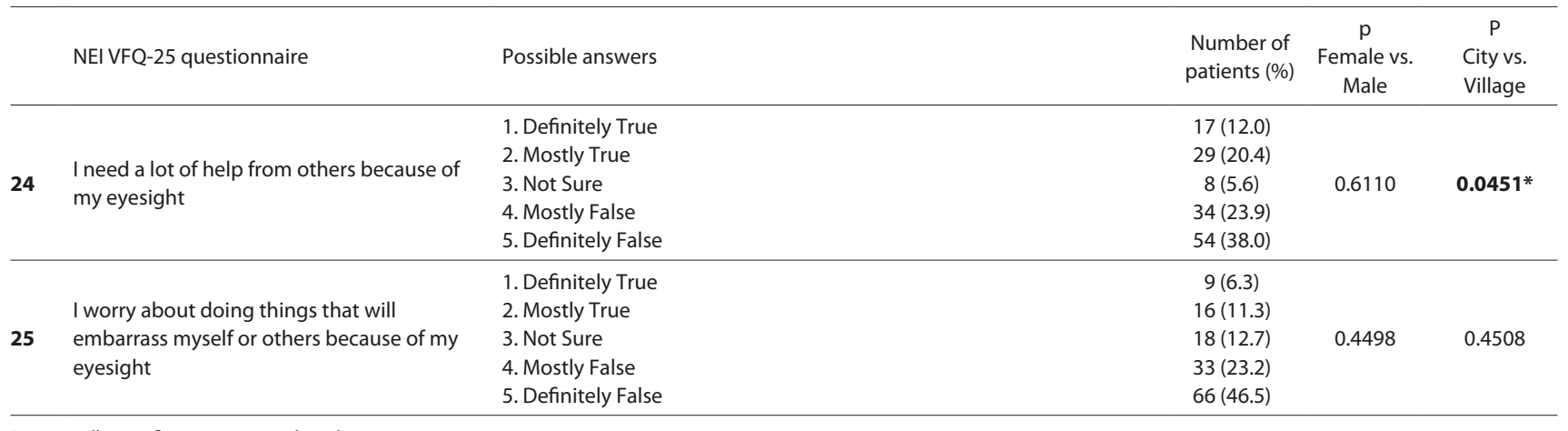

*statistically significant; $\wedge$ statistical tendency

The questions to which answers obtained statistically significant results are presented below:
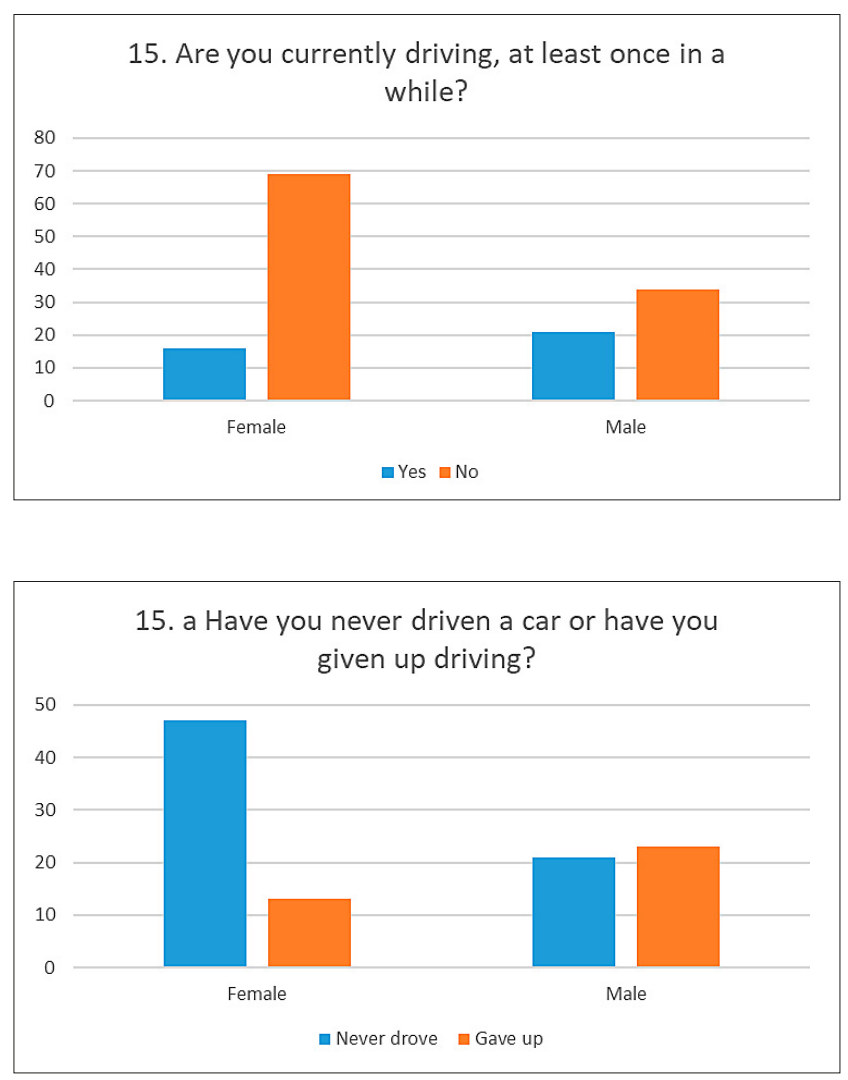

15. b IF YOU GAVE UP DRIVING: Was that mainly because of your eyesight, mainly for some other reason, or because of both your eyesight and other reasons?

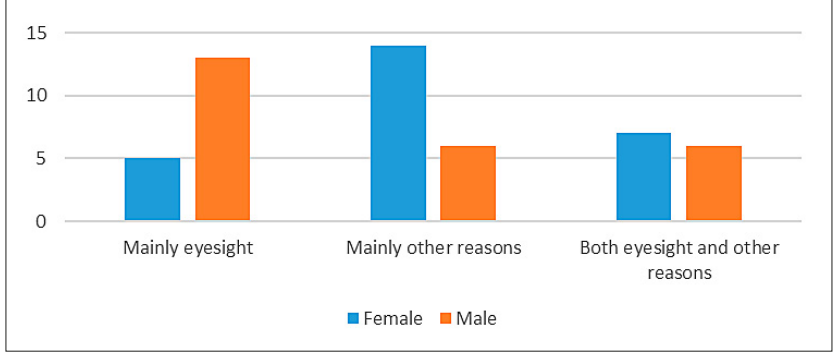

\section{In general, would you say your overall health is:}

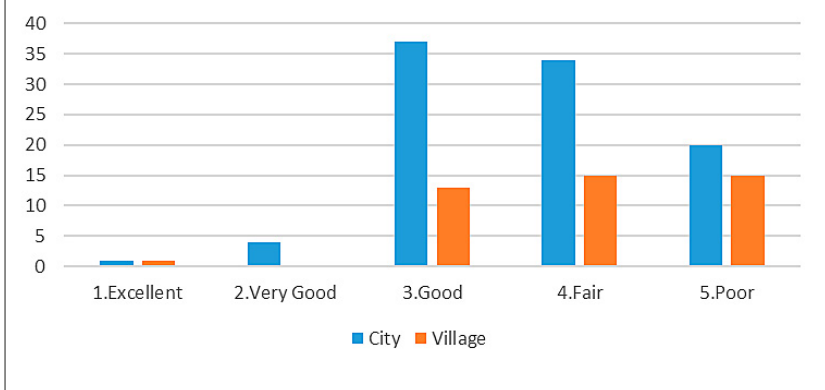

2. At the present time, would you say your eyesight using both eyes (with glasses or contact lenses, if you wear them) is excellent, good, fair, poor, or very poor or are you completely blind?

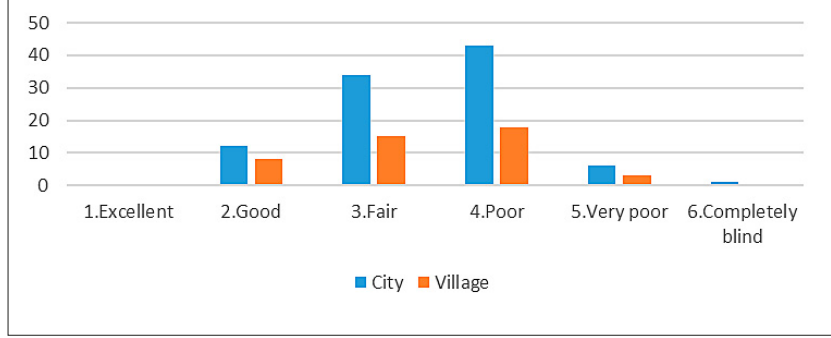

15. Are you currently driving, at least once in a while?

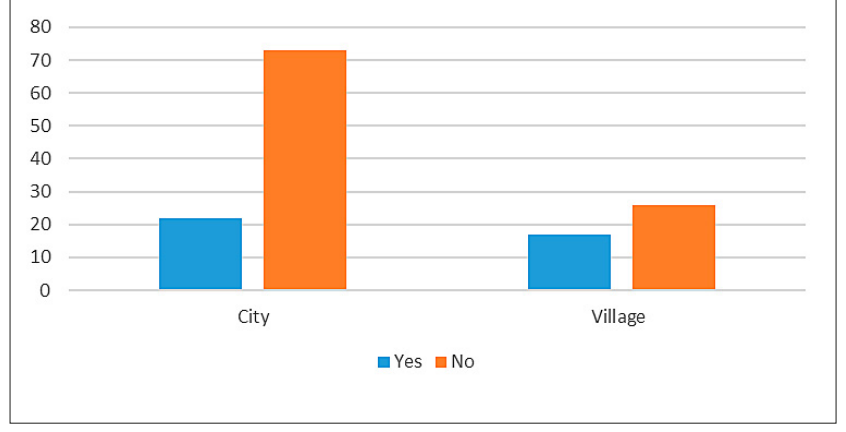




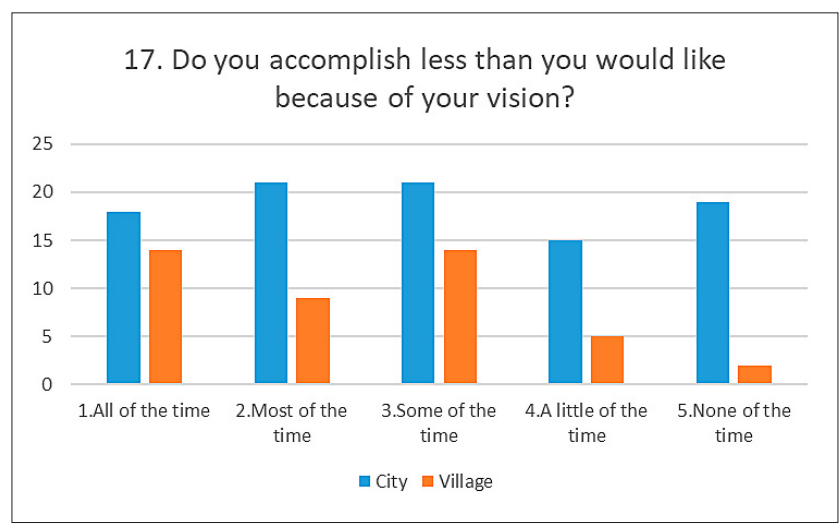

21. I feel frustrated a lot of the time because of my eyesight

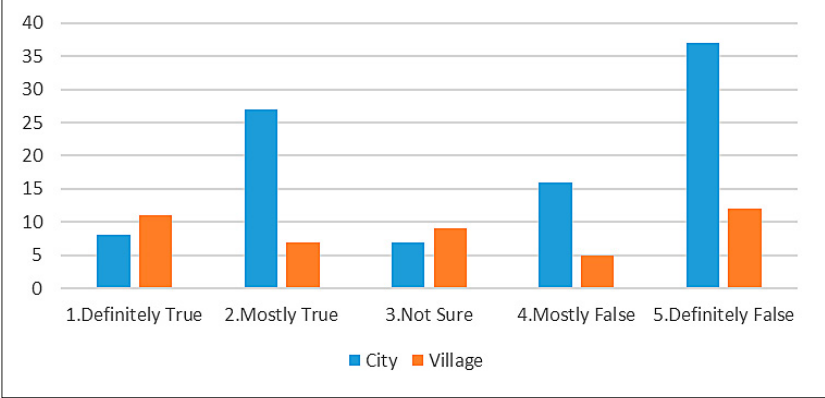

24. I need a lot of help from others because of my eyesight

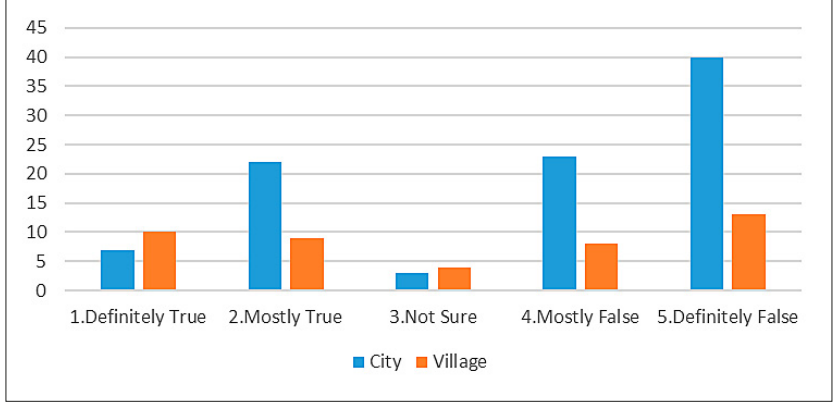

Among the NEI VFQ-25 questionnaire, NEI item \# 4 showed a tendency that women complained about moderate and severe discomfort and pain more often than men $(\mathrm{p}=0.09)$. Most of the patients did not drive a car, even before the onset of the disease (females vs. males: $81 \%$ vs. $62.9 \% ; \mathrm{p}=0.0112)$. $62.8 \%$ of males gave up driving a car vs. $25.8 \%$ of females $(\mathrm{p}=0.003$. The parameter regarding driving difficulties showed that $50 \%$ of males gave up driving because of their eyesight, whereas only $20.8 \%$ females decided to gave up driving for the same reason $(\mathrm{p}=0.033)$.

In the current study, the population was divided into two groups according to their origin - village or city. There was a significant difference between the patients from the city and the village regarding general health condition and eyesight. A tendency was observed that respondents from the village complained more often about extreme difficultywith or even stopped reading newspapers, street signs or the names of stores, than patients from the city $(\mathrm{p}=0.08)$. Question number 15 on the NEI-VFQ-25 demonstrated that $22.8 \%$ of the patients from the city were driving vs. $40.47 \%$ of patients from the village $(p=0.047)$. In the group of patients who were not currently driving a car, $44.2 \%$ of city residents and only $25 \%$ of villagers had given up driving $(\mathrm{p}=0.068)$. A relevant difference was observed in the answers to question number 17: rural patients felt that they achieved much less because of their eyesight, while the patients from the citdid not perceive such an association $(\mathrm{p}=0.06)$. City patients did not report any relationship between frustration and visual acuity or the need for help from others, in contrast to villagers (Tab. 2).

\section{DISCUSSION}

Central vision is severely affected secondary to geographic atrophy, disciform scar, or choroidal neovascularization in patients with advanced AMD. Previous studies have used the NEI VFQ-25 to confirm that AMD reduces VisionRelated Quality of Life (VRQoL), especially with activities related to central vision, such as reading, driving and facial recognition [8]. Therefore, the presented study investigated which personal factors are significantly impaired, and additionally how it correlates with environmental factors.

Exudative AMD is a chronic disease that rapidly reduces central vision. Geographical, population and sociodemographic differences may lead to variable results regarding the scores on depression, anxiety and qualityof-life scales. These results can also be influenced by factors relating to patients' expectations and habits. The study also attempted to asses patients' beliefs and fears relating to the disease, and the ways in which they react to the disease in different environmental circumstances.

The NEI-VFQ-25 test is among the most commonly used vision-specific QoL scales. It is well known and documented using this test for glaucoma patients and their visual impairments has great impact on VRQoL [9-11]. There are also few studies concerning AMD patients, e.g. Orr et al. found that NEI-VFQ-25 scores were positively correlated with good vision in AMD patients [2]. In the Age-Related Eye Disease Study, the researchers assessed NEI-VFQ-25 scores twice, with a four-year interval between assessments, and demonstrated that there was a significant association between NEI-VFQ-25 scores and the progression of AMD and vision loss [5]. However, none of the studies investigated the interaction between the place of residence and selfreported vision related quality of life.

The findings of the current study revealed that there are some differences between the subpopulations of patients with AMD living in rural and urban environments. It is interesting to note that difficulties in reading were more notably mentioned by rural patients. This suggests that prescribing low-vision devices in rural areas may be less common or probably that patients are not so well informed about such conveniences. Furthermore, rural patients felt that they achieved much less because of their vision loss in contrast to urban patients who did not perceive such an association. Presumably, this situation has something in common with previously mentioned reading difficulties and psychological distress caused by frustration or loss of independence.

Another problem that occurred to be significantly different in these two subgroups was driving a car. $44.2 \%$ of urban 
patients declared having given up driving, in contrast to only $25 \%$ of the rural patients. This could be explained by the availability of public transport in the cities and much less so in in rural areas. Thus, patients living in urban area who feel uncertain about their eyesight may choose other options than driving a car, whereas in the villages there are fewer such possibilities. This feature appears even stronger considering the fact that in the current study $40.47 \%$ of the rural patients were drivers, compared to $22.8 \%$ of patientsin the is probably the result of public transport diversification.

The third issue that is different in these two subpopulations of AMD patients is that rural patients felt that they achieved much less because of their visual impairment, while urban patients saw no such association.

None of these problems have been previously studied in any other country in relation to place of residence, it is therefore impossible to generalize that this is a global problem. In Poland, such discrepancies are also easily visible also in patients suffering from other diseases [12].

\section{CONCLUSIONS}

Rural patients in Poland experience a poorer level of visionrelated function than urban patients concerning reading capability, and report a lower acceptance of the disease. More information and counseling should be given in clinical settings to help rural patients to adapt to their loss of central vision, and to match appropriate low-vision aids.

\section{REFERENCES}

1. Ćwirlej-Sozańska A, Sozański B, Wiśniowska-Szurlej A, WilmowskaPietruszyńska A. Quality of life and related factors among older people living in rural areas in south-eastern Poland. Ann Agric Environ Med. 2018; 25(3): 539-545. doi: 10.26444/aaem/93847

2. Orr P, Rentz AM, Margolis MK, Revicki DA, Dolan CM, Bressler NM, et al. Validation of the National Eye Institute Visual Function Questionnaire-25 (NEI VFQ-25) in age-related macular degeneration. Invest Ophthalmol Vis Sci. 2011; 52(6): 3354-3359. doi: 10.1167/iovs.105645
3. Xu K, Gupta V, Bae S, Sharma S. Metamorphopsia and vision-related quality of life among patients with age-related macular degeneration. Can J Ophthalmol. 2018; 53(2): 168-172. doi: 10.1016/j.jcjo.2017.08.006

4. Riva I, Legramandi L, Rulli E, Konstas AG, Katsanos A, Quaranta L, Italian Study Group On Qol, et al. Vision-related quality of life and symptom perception change over time in newly-diagnosed primary open angle glaucoma patients. Glaucoma. Sci Rep. 2019; 9(1): 6735. doi: 10.1038/s41598-019-43203-9

5. Age-Related Eye Disease Study Research Group. The Age-Related Eye Disease Study (AREDS): design implications. AREDS report no. 1. Control Clin Trials. 1999; 20(6): 573-600. doi: 10.1016/s01972456(99)00031-8

6. Nordmann JP, Viala M, Sullivan K, Arnould B, Berdeaux G. Psychometric Validation of the National Eye Institute Visual Function Questionnaire - 25 (NEI VFQ-25) French version: in a population of patients treated for ocular hypertension and glaucoma. Pharmacoeconomics. 2004; 22(3): 197-206. doi: 10.2165/00019053-200422030-00005

7. Yang L, Shi X, Tang X. Associations of subjective and objective clinical outcomes of visual functions with quality of life in Chinese glaucoma patients: a cross-sectional study. BMC Ophthalmol. 2019; 19(1): 166. doi: 10.1186/s12886-019-1176-0

8. Inan S, Cetinkaya E, Duman R, Dogan I, Inan UÜ. Quality of life among patients with age-related severe macular degeneration assessed using the NEI-VFQ, HADS-A, HADS-D and SF-36 tests. A crosssectional study. Sao Paulo Med. 2019; 137(1): 15-32. doi: 10.1590/15163180.2018.0195071218

9. Lane J, Rohan EMF, Sabeti F, Essex RW, Maddess T, McKone E, et al. Impacts of impaired face perception on social interactions and quality of life in age-related macular degeneration: A qualitative study and new community resources. PLoS One. 2018; 13(12): e0209218. doi: 10.1371/ journal.pone.0209218

10. Mangione CM, Lee PP, Gutierrez PR, Spritzer K, Berry S, National Eye Institute Visual Function Questionnaire Field Test Investigators, et al. Development of the 25-item National Eye Institute Visual Function. Arch Ophthalmol. 2001; 119: 1050-1058. doi: 10.1001/ archopht.119.7.1050

11. Roh M, Selivanova A, Shin HJ, Miller JW, Jackson ML. Visual acuity and contrast sensitivity are two important factors affecting vision-related quality of life in advanced age-related macular degeneration. PLoS One. 2018; 13(5): 471-75. doi: 10.1371/journal.pone.0196481

12. Ryu SJ, Lee WJ, Tarver LB, Shin YU, Kang MH, Cho HY, et al. Depressive Symptoms and Quality of Life in Age-related Macular Degeneration Based on Korea National Health and Nutrition Examination Survey (KNHANES). Korean J Ophthalmol. 2017; 3(5): 413-423. https://doi. org/10.3341/kjo.2016.0086

13. Bian W, Wan J, Smith G, Li S, Tan M, Zhou F. Domains of health-related quality of life in age-related macular degeneration: a qualitative study in the Chinese cultural context. BMJ Open. 2018; 8(4): e018756. doi: 10.1136/bmjopen-2017-018756 